\title{
Development of novel oncology biomarkers for cancer
}

\author{
Nathan Yoganathan \\ From 5th Congress of the Brazilian Biotechnology Society (SBBIOTEC) \\ Florianópolis, Brazil. 10-14 November 2013
}

\section{Introduction}

According to American Cancer Society projections for 2014, approximately 1.5 million new cancers are expected to be diagnosed and more than several hundred patients are expected to die of cancer, with more than $90 \%$ of these cancers being solid tumours (ACS, 2010). Epithelial cell-derived cancers comprise approximately $80-85 \%$ of all cancers, and include, amongst others, breast, bladder, lung, pancreatic, thyroid and prostate cancers [1-4]. Presently, breast cancer is the most common cancer among women worldwide as more than 1 in 4 cancers in women (about 28\%) are of the breast, and thyroid cancer is the most common epithelial cell-derived malignancy of the endocrine glands $[4,5]$. These cancers may exhibit no signs in its early stages. Further, the aggressive cases are difficult to detect and when undetected, prognosis deteriorates rapidly.

Neutralization antibodies targeted to genes associated with cancer is a good strategy to detect cancer at early stages among many treatment approaches because of its high specificity and affinity. KalGene is developing a multi-protein assay to identify aggressive epithelial cancers, including breast, colon, and prostate, thyroid cancers. We have successfully developed several monoclonal antibodies against important biomarkers. Our monoclonal antibodies have shown excellent affinity and specific reactivity to the recombinant protein and cell lysates.

Purified monoclonal antibodies were tested on tissue microarrays (TMA). Tissue microarray technology allows a massive acceleration of studies correlating molecular in situ bindings with clinico-pathological information. In this method, minute tissue cylinders (diameter $0.6 \mathrm{~mm}$ ) are removed from hundreds of different primary tumour blocks and subsequently brought into one empty 'recipient' paraffin block. Sections from

KalGene Pharmaceuticals Inc, Canada 
5. Ricci-Vitiani L, Lombardi DG, Pilozzi E, Biffoni M, Todaro M, Peschle C, De Maria R: Identification and expansion of human colon-cancer-initiating cells. Nature 2007, 445(7123):111-115.

doi:10.1186/1753-6561-8-S4-016

Cite this article as: Yoganathan: Development of novel oncology biomarkers for cancer. BMC Proceedings 2014 8(Suppl 4):016.

Submit your next manuscript to BioMed Central and take full advantage of:

- Convenient online submission

- Thorough peer review

- No space constraints or color figure charges

- Immediate publication on acceptance

- Inclusion in PubMed, CAS, Scopus and Google Scholar

- Research which is freely available for redistribution

Submit your manuscript at www.biomedcentral.com/submit

() Biomed Central 